\title{
Margaret McCartney: Dishonourable New Year honours
}

\author{
Margaret McCartney general practitioner, Glasgow
}

This is likely to upset some of my nicest friends-those called Sir or Dame, or those who sign off with CBE or OBE (commander or officer of the Most Excellent Order of the British Empire). I apologise wholeheartedly. But, as the newspapers publish the names of those who have accepted the honours of the land in the New Year Honours list, and as the medical press publishes them to inevitable looks of envy, there should be room for caution.

To what extent does our honours system encourage people to think that it's better to work on the inside of an institution rather than the outside? Clearly, some people genuinely think that insiders have a more direct route to power, and more opportunity to effect change, than outsiders, who battle after 9 pm with a glass of wine in one hand and a computer mouse in the other. We often just piss people off rather than accomplish change. But, because of the honours system, we can't be sure that some people don't opt to work on the inside of an institution to ensure that they win a gong sometime in their career.

The honours system is the icing on our elitist societal cake. For every good hearted volunteer, lollipop man, fundraiser, or campaigner being honoured at Buck House, loads of others receive higher titles for simply doing their job-especially in politics or the civil service - which makes me wonder about bias. And the honours system is sexist.

It's also unreliable: Mugabe and Savile were both knighted. The honours system is at once pointless and pointed. The ability to put a title before, or letters after, one's name, after selection through an opaque process with no transparent external validation, appeals to vanity and is nurtured by pomposity. What good do these honours do, other than create division and hierarchies? Researchers found no evidence that being a "Sir" led to a higher response rate to letters sent to deans of medical schools and royal colleges. ${ }^{1}$
The need to speak truth to power is crucial, but is this well served by the honours system? It may have more insidious effects: I wonder whether the actions of several people in senior medical positions would be the same but for the presence of the honours hierarchy.

Does this system change how one seeks or expresses views in medical politics, or how one interacts with policy makers? Choosing to get things done inside institutions is already risky, because compromise is a common consequence-but how do we know that compromises aren't being made to win an elite title for oneself?

Competing interests: I have read and understood BMJ policy on declaration of interests and declare the following interests: I'm an NHS GP partner, with income partly dependent on Quality and Outcomes Framework points. I've written two books and earn from broadcast and written freelance journalism. I'm an unpaid patron of Healthwatch. I make a monthly donation to Keep Our NHS Public. I'm a member of Medact. I'm occasionally paid for time, travel, and accommodation to give talks or have locum fees paid to allow me to give talks but never for any drug or public relations company. I was elected to the national council of the Royal College of General Practitioners in 2013 and am chair of its standing group on overdiagnosis. I have invested a small amount of money in a social enterprise, Who Made Your Pants? Provenance and peer review: Commissioned; not externally peer reviewed.

Follow Margaret on Twitter, @mgtmccartney

1 Clarke M, Clarke L, Clarke T. Yes Sir, no Sir, not much difference Sir. J R Soc Med 2007;100:571-2.

Cite this as: BMJ 2016;352:i28

๑) BMJ Publishing Group Ltd 2016 